\title{
PENGARUH KUALITAS PRODUK TERHADAP MINAT BELI KONSUMEN PADA SEPEDA MOTOR SUZUKI JENIS SATRIA FU DI BANDAR LAMPUNG
}

\author{
Annisa Soraya ${ }^{(1)}$, Sodirin ${ }^{(2)}$, Hujaimatul Fauziah ${ }^{(3)}$ \\ Fakultas Ekonomi Universitas Sang Bumi Ruwa Jurai \\ annisa.soraya@gmail.com,sodirin@fe.saburai.ac.id,hujaimatul.fauziah@fe.saburai.ac.id
}

\begin{abstract}
Abstrak. PT. Suzuki memproduksi produk yaitu motor jenis suzuki satria FU yang memiliki cc 150cc dan paling besar untuk dikelasnya, seiring perkembangan jaman banyak produsen untuk mengembangkan produknya untuk bersaing dipasaran. Penelitian ini bertujuan untuk mengetahui seberapa besar pengaruh kualitas produk terhadap minat beli konsumen pada sepeda motor jenis satria FU di Bandar Lampung. Hipotesis yang penulis ajukan adalah "Diduga kualitas produk berpengaruh terhadap minat beli konsumen pada sepeda motor Suzuki jenis satria FU". Metode penelitian ini menggunakan metode Asosiatif. Penelitian ini adalah semua konsumen yang membeli motor suzuki jenis satria FU 150 yang selanjutnya dihitung menggunakan rumus slovin sehingga diperoleh sampel dari bulan Juni hingga Agustus 2016 sebanyak 100 responden. Teknik pengumpulan data menggunakan skala Likert. Hasil uji analisis regresi sederhana $\mathrm{Y}=13,672+0,418 \mathrm{X}$, dan nilai $\mathrm{R}^{2}$ Square sebesar 0,331 menunjukkan bahwa minat beli konsumen $(\mathrm{Y})$ dipengaruhi Kualitas produk sebesar 33,1\% sisanya sebesar 66,9\% dipengaruhi oleh variabel lain. Dilihat dari t tabel $(1,660)$, t hitung hasil penelitian menunjukkan bahwa variabel kualitas Produk sebesar 6,968 berpengaruh secara signifikan terhadap Minat beli Konsumen Pada Sepeda Motor Suzuki Satria FU Di Bandar Lampung.
\end{abstract}

Kata kunci: Asosiatif, Kualitas, Minat, Produk.

\section{PENDAHULUAN}

Diera globalisasi ini persaingan bisnis menjadi sangat tajam, baik di pasar nasional (domestik) maupun di pasar internasional atau global, akibatnya timbul persaingan dalam menawarkan produk-produk yang berkualitas dengan harga yang mampu bersaing di pasaran. Berdasarkan tingkat kehidupan masyarakat yang semakin meningkat, maka kebutuhan masyarakat terhadap barang juga akan semakin meningkat. Hal ini membawa pengaruh terhadap perilaku mereka dalam memilih barang yang akan mereka beli ataupun yang mereka anggap paling sesuai dan benarbenar dapat memenuhi kebutuhan dan keinginan mereka.

Orang memuaskan kebutuhan dan keinginan mereka dengan produk. Produk yang berkualitas dengan harga bersaing merupakan kunci utama dalam memenangkan persaingan, yang pada akhirnya akan dapat memberikan nilai kepuasan yang lebih tinggi kepada konsumen. Konsumen kini memiliki tuntutan nilai yang jauh lebih besar dan beragam karena dihadapkan pada berbagai pilihan berupa barang maupun jasa yang dapat mereka beli. Dalam hal ini penjual harus dapat memberikan kualitas produk yang baik. Begitu pula dengan kelengkapan produk yang ditawarkan juga sangat mempengaruhi minat beli konsumen.

Produk sebagai hasil dari kegiatan produksi yang akan mempunyai wujud tertentu. Disamping itu akan terdapat tenggang waktu (yang betapapun kecilnya) antara saat diproduksinya produk tersebut dengan saat dikonsumsinya produk yang bersangkutan oleh konsumen produk tersebut. Oleh karena itu, setiap produk 
harus mempunyai keunggulan dibandingkan dengan produk lainnya. Keunggulan ini dengan memberikan nilai yang tinggi terhadap konsumen. Dalam mencapai nilai tersebut dapat dilakukan dengan menanamkan kualitas produk yang kuat kepada konsumen.

Kualitas diukur melalui sudut pandang konsumen terhadap kualitas produk itu sendiri, sehingga selera konsumen disini sangat berpengaruh. Jadi dalam mengelolah kualitas suatu produk harus sesuai dengan kegunaan yang diinginkan oleh konsumen. Dalam hal ini yang penting adalah menjaga konsistensi dari output produk pada tingkat kualitas yang diinginkan dan diharapkan konsumen.

Dilihat dari data spesifikasi motor Suzuki satria FU lebih unggul bila dibandingkan dengan motor pesaingnya yaitu Yamaha Jupiter MX. Kesesuaian dengan spesifikasi suzuki satria FU memiliki kapasitas $150 \mathrm{cc}$, DOHC (Double Overhead Camshaft) yaitu pengapian yang besar sehingga motor bisa lebih cepat, 6 speed, berat kosong $90 \mathrm{~kg}$, sedangkan Jupiter MX memiliki kapasitas 135cc, 5 speed, berat kosong 109kg, SOHC (Single Overhaed Camshaft) yaitu pengapian yang lebih kecil.

Selain itu motor ini mempunyai desain yang tidak menunjang bagi pengendaranya karena posisi badan pengendara harus menunduk menyesuaikan dengan bentuk motor tersebut. Suzuki satria FU sendiri terkesan boros dalam bahan bakar dikarenakan dengan cc yang cukup besar dikelas motor bebek yaitu $150 \mathrm{cc}$ dan daya tampung bahan bakarnya hanya sebesar 4,9liter, jika motor tersebut dibawa dalam perjalanan jauh akan sering untuk mengisi bahan bakar. Dibandingkan dengan Yamaha Jupiter MX yang hanya memiliki kapasitas bahan bakar hanya 4liter, tetapi motor ini lebih irit karena ccnya hanya 135.

Suzuki satria FU memiliki bentuk bodi yang tidak sesuai dengan kapasitas mesin yang tinggi sehingga menimbulkan ketidak seimbangan pengemudi ketika mengendarai motor suzuki satria FU dengan kecepatan maksimal. Bila dilihat dari daya tahan busi, busi adalah komponen yang paling harus mendapat perhatian ini karena busi pada motor satria FU sering kemasukan air ketika hujan atau mencuci motor tersebut, ini disebabkan jarak sasis dan kepala silinder renggang.

Air mudah masuk karena celah yang renggang dan posisi mesin vertikal, tambah lagi desain lubang busi dipenutup kepala silinder ada lubang plus antara lingkaran penutup busi sehingga air dapat merembas akibatnya api busi tidak bisa besar sehingga susah hidup, ini memberikan dampak yang besar kepada kinerja motor satria FU. Selain rentan dengan kerusakan dan bahan bakar terlalu boros, motor suzuki satria FU juga terlalu mahal untuk dikelas motor bebek.

Kualitas produk merupakan pemahaman bahwa produk yang ditawarkan oleh penjual mempunyai nilai jual lebih yang tidak dimiliki oleh produk pesaing. Oleh karena itu suatu perusahaan berusaha memfokuskan pada kualitas produk dan membandingkannya dengan produk yang ditawarkan oleh perusahaan pesaing. Kemudian perusahaan akan berusaha memberikan kualitas yang baik dari produk lainnya, supaya menimbulkan keinginan individu untuk meyakinkan bahwa barang tersebut mempunyai keunggulan dengan produk lain, sehingga individu ingin memiliki barang tersebut dengan cara membeli.

Minat membeli merupakan aktivitas psikis yang timbul karena adanya perasaan dan pikiran terhadap suatu barang atau jasa yang diinginkan. Berdasarkan uraian dan penjelasan tersebut, maka peneliti tertarik untuk melakukan penelitian dengan judul: "Pengaruh Kualitas Produk Terhadap Minat Beli Konsumen Sepeda Motor 


\section{Suzuki Jenis Satria FU Di Bandar Lampung".}

\section{KAJIAN TEORI}

\section{Pemasaran}

Pemasaran dimulai dengan pemenuhan kebutuhan manusia yang kemudian bertumbuh menjadi keinginan manusia. Kebutuhan dan keinginan itu menciptakan suatu keadaan yang menyenangkan dalam diri seseorang dan harus dipecahkan melalui kepemilikan produk untuk memuaskan kebutuhan tertentu. Pemasar ini sebaiknya memiliki pengetahuan dalam konsep dan prinsip pemasaran agar kegiatan pemasaran dapat tercapai sesuai dengan kebutuhan dan keinginan manusia terutama pihak konsumen yang dituju.

Menurut Asosiasi Pemasaran Amerika, pengertian pemasaran sebagai berikut : Kotler (2007), menyatakan bahwa "pemasaran adalah satu fungsi organisasi dan seperangkat proses untuk menciptakan, mengomunikasikan, dan menyerahkan nilai kepada pelanggan dan mengelola hubungan pelanggan dengan cara yang menguntungkan organisasi dan para pemilik sahamnya".

Philip Kotler dan Kevin Lane Keller (2007) pemasaran adalah sebagai berikut : Suatu proses sosial yang didalamnya individu dan kelompok mendapatkan apa yang mereka butuhkan dan inginkan dengan menciptakan, menawarkan, dan secara bebas mempertukarkan produknya yang bernilai dengan pihak lain.

Sedangkan menurut Ali Hasan Pemasaran (marketing) (2009) merupakan sebuah konsep ilmu dalam strategi bisnis yang bertujuan untuk mencapai kepuasaan berkelanjutan bagi stakeholder (pelanggan, karyawan, pemegang saham). Sebagai ilmu, marketing merupakan ilmu pengetahuan yang obyektif, yang diperoleh dengan penggunaan instrumen-instrumen tertentu untuk mengukur kinerja dari efektifitas bisnis dalam membentuk, mengembangkan, mengarahkan pertukaran yang saling menguntungkan dalam jangka panjang antara produsen dan konsumen atau pemakai.

\section{Bauran Pemasaran (Marketing Mix)}

Bauran pemasaran merupakan inti dari pemasaran dalam memasarkan produk dari produsen sampai ke konsumen akhir. Menurut Kotler (2005), marketing mix adalah seperangkat alat pemasaran yang digunakan perusahaan untuk mencapai tujuan pemasarannya dalam pasar sasaran.

Menurut William J. Stanton dalam Swastha dan Sukotjo (2010) Bauran Pemasaran adalah kombinasi dari empat variabel atau kegiatan yang merupakan inti dari sistem pemasaran perusahaan perusahaan, yaitu produk, harga, kegiatan promosi dan saluran distribusi. Perusahaan tidak hanya sekedar memilih kombinasi yang terbaik saja, tetapi juga harus dapat mengkoordinasikan berbagai macam elemen dan bauran pemasaran tersebut untuk dapat melaksanakan program pemasaran secara efektif.

Marketing Mix harus selalu dapat bersifat dinamis, selalu dapat menyesuaikan diri dengan lingkungan eksternal maupun internal. Faktor eksternal yaitu faktor diluar jangkauan perusahaan antara lain terdiri dari pesaing, teknologi, peraturan pemerintah, keadaan perekonomian, dan lingkungan sosial budaya. Sedangkan faktor internal adalah variabel-variabel yang terdapat dalam marketing mix yakni : Product (produk), Price (harga), Place (tempat), Promotion (promosi).

Dari definisi-definisi diatas maka dapat diambil kesimpulan bahwa marketing mix merupakan kombinasi dan empat variabel yang merupakan inti dari sistem pemasaran perusahaan dan dapat dikendalikan oleh perusahaan. 


\section{Produk}

Produk merupakan variabel bauran pemasaran yang utama. Produksi sering diartikan kumpulan atribut secara fisik dalam bentuk nyata, dalam tujuan sebenarnya produk tidak hanya meliputi atribut fisik saja, tetapi juga mencakup sifat-sifat non fisik seperti harga, nama penjual dan sebagainya. Semua unsur tersebut dipandang sebagai alat pemuas kebutuhan konsumen.

Pengertian produk menurut Kotler dan Amstrong (2010) produk adalah sesuatu yang dapat ditawarkan kedalam pasar untuk diperhatikan, dimiliki, dipakai atau dikonsumsi sehingga dapat memuaskan keinginan dan kebutuhan yang termasuk didalamnya adalah objek fisik tapi juga suatu kompleks dari sifat-sifat nyata dan tidak nyata, termasuk hal-hal seperti jaminan, pengepakan, warna, desain, termasuk jasa-jasa. Menurut Kotler dan Armstrong (2010) produk adalah suatu sifat yang kompleks, baik yang dapat diraba maupun yang tidak dapat diraba, termasuk kemasan, harga, prestige perusahaan, dan pelayanan jasa perusahaan yang diterima oleh pembeli untuk memuaskan keinginan dan kebutuhannya.

Kualitas produk merupakan hal yang perlu mendapat perhatian utama disuatu perusahaan, karena kualitas menjadi komponen yang ada dalam produk yang diharapkan, konsumen menginginkan mutu suatu produk yang sesuai seperti keinginan mereka dalam memenuhi kebutuhannya. Pada hakikatnya seseorang membeli barang atau jasa untuk memuaskan kebutuhan atau keinginan. Seseorang membeli barang bukan hanya fisik semata, melainkan manfaat yang ditimbulkan oleh barang atau jasa yang dibeli. Maka dari itu, perusahaan dituntut untuk selalu kreatif, dinamis, dan berfikir luas.

Pemasar yang tidak memperhatikan kualitas produk yang ditawarkan akan menanggung tidak puasnya konsumen sehingga penjualan produknya pun cenderung akan menurun. Jika suatu produk dibuat sesuai dimensi kualitas, dan sesuai memberikan harga yang ditawarkan maka akan mempengaruhi minat beli konsumen untuk membeli. Suatu produk memiliki nilai yang berkualitas bukan dari produsen, melainkan oleh konsumen. Sehingga yang berhak memberi evaluasi apakah yang telah dibeli dan dikonsumsinya itu sendiri dengan harapan awalnya atau tidak adalah konsumen itu sendiri.

Menurut Kotler (2007), Kualitas produk adalah kemampuan suatu barang untuk memberikan hasil / kinerja yang sesuai atau melebihi dari apa yang diinginkan pelanggan. Menurut Fandy Tjiptono (2012): Kualitas produk merupakan suatu kondisi dinamis yang berhubungan dengan produk, jasa, manusia, proses dan lingkungan yang memenuhi atau melebihi harapan. Menurut Clark (2007): mendefinisikan kualitas sebagai " how consistenly the product or service delivered meets or exceeds the customer's (internal or eksternal) expectation and needs" (seberapa konsisten produk atau jasa yang dihasilkan dapat memenuhi pengharapan dan kebutuhan internal dan eksternal pelanggan).

\section{Minat Beli Konsumen}

Menurut Suntara (2005) minat membeli merupakan aktivitas psikis yang timbul karena adanya perasaan dan pikiran terhadap suatu barang atau jasa yang diinginkan. Minat adalah yang dialami seseorang dimana orang tersebut ingin berbuat sesuatu untuk mencapai keinginan, minat seseorang lebih cenderung dipengaruhi oleh adanya rangsangan. Minat beli konsumen adalah keinginan atau hasrat seseorang akan sesuatu yang ditawarkan.

Beli adalah dimana konsumen memperoleh produk dan jasa. Pengaruh 
situasi sangat lazim selama pembelian. Sebagai contoh yang sederhana pertimbangkan perubahan hebat dalam kepekaan konsumen akan harga didalam situasi pembelian.

Konsumen adalah suatu proses dan pembelian hanyalah satu tahap. Ada banyak pengaruh yang mendasari, dari motivasi internal hingga pengaruh sosial dari berbagai jenis. Namun, motivasi dan prilaku dapat dimengerti, walaupun secara tidak sempurna melalui penelitian. Minat yang ada dalam diri seseorang konsumen sangat mempengaruhi dalam proses keputusan pembelian, karena apabila seseorang konsumen mempunyai perhatian terhadap barang atau jasa maka konsumen tersebut akan melakukan usaha untuk membeli barang atau jasa tersebut.

Berdasarkan uraian di atas maka pengertian membeli adalah pemusatan perhatian terhadap sesuatu yang disertai dengan perasaan senang terhadap barang tersebut, kemudian minat individu tersebut menimbulkan keinginan sehingga timbul perasaan yang meyakinkan bahwa barang tersebut mempunyai manfaat sehingga individu ingin memiliki barang tersebut dengan cara membayar atau menukar dengan uang. Minat membeli adalah suatu tahapan terjadinya keputusan untuk membeli suatu produk.

Susanto (2006) menyatakan bahwa individu dalam mengambil keputusan untuk membeli suatu barang atau jasa ditentukan oleh dua faktor, yaitu :

1. Faktor luar atau faktor lingkungan yang mempengaruhi individu seperti lingkungan kantor, keluarga, lingkungan sekolah dan sebagainya.

2. Faktor dalam diri individu, seperti kepribadiannya sebagai calon konsumen.

Beberapa faktor yang mempengaruhi minat, yaitu : a. Perbedaan pekerjaan, artinya dengan adanya perbedaan pekerjaan seseorang dapat diperkirakan minat terhadap tingkat pendidikan yang ingin dicapainya, aktivitas yang dilakukan, penggunaan waktu senggangnya, dan lain-lain.

b. Perbedaan sosial ekonomi, artinya seseorang yang mempunyai sosial ekonomi tinggi akan lebih mudah mencapai apa yang diinginkannya daripada yang mempunyai sosial ekonomi rendah.

c. Perbedaan hobi atau kegemaran, artinya bagaimana seseorang menggunakan waktu senggangnya.

d. Perbedaan jenis kelamin, artinya minat wanita akan berbeda dengan minat pria, misalnya dalam pembelanjaan.

e. Perbedaan usia, artinya usia anak-anak, remaja, dewasa dan orangtua akan berbeda minatnya terhadap suatu barang, aktivitas benda dan seseorang.

\section{METODE PENELITIAN}

\section{Objek Penelitian}

Objek didalam penelitian ini adalah para pengguna motor suzuki satria FU di Bandar Lampung dengan aspek penelaahan yang berhubungan dengan kualitas produk dan minat beli terutama pada motor suzuki satria FU melalui penelaahan dokumen yang berlangsung pada bulan Juni hingga Agustus 2016 di PT Suzuki, Jalan RA Kartini, Bandar Lampung.

\section{Metode dan Teknik Pengumpulan Data}

Menurut sugiyono (2006) berpendapat bahwa metodologi penelitian adalah cara ilmiah untuk mendapatkan data dengan 
tujuan dan kegunaan tertentu dan penelitian itu didasarkan pada ciri-ciri keilmuan yaitu nasional, empiris dan sistematis. Dalam penelitian ini penelitian menggunakan metode asosiatif atau penelitian berdasarkan hubungan yang bertujuan untuk mengetahui hubungan antar dua variabel atau lebih. Metode asosiatif merupakan suatu penelitian yang mencari hubungan sebab akibat antar satu variabel independen dengan variabel dependen. Pengujian hipotesis dilakukan dengan menggunakan perhitungan statistika yang digunakan untuk menguji variabel $X$ terhadap variabel $\mathrm{Y}$ yang diteliti.

Dalam penelitian ini jenis data yang diperlakukan adalah :

a. Data Primer

Data primer merupakan data dasar yang akan diperoleh langsung tanpa perantara orang atau lembaga lain sebagai pihak ketiga. Data primer ini diperoleh dengan wawancara melalui responden dengan menggunakan daftar pertanyaan.

\section{b. Data Sekunder}

Data skunder merupakan data yang diperoleh melalui orang lain yang berhubungan dengan permasalahan yang dipecahkan. Data sekunder ini diperoleh melalui cara studi dokumenter yaitu mengumpulkan dan mempelajari brosurbrosur serta dokumen organisasi.

\section{Sampel dan Populasi}

Metode pengambilan sampel dalam penelitian ini adalah nonprobability sampling dengan menggunakan teknik accidental sampling. Teknik accidental adalan penentuan sampel berdasarkan kebetulan, yaitu siapa saja yang secara kebetulan bertemu dengan peneliti dapat digunakan sebagai sampel, bila dipandang orang yang kebetulan ditemui itu cocok sebagai sumber data (Sugiyono, 2006).
Uma Sekaran (2006) berpendapat bahwa populasi adalah keseluruhan kelompok orang, kejadian, atau hal minat yang ingin peneliti investigasi. Dalam penelitian ini mengambil satu karakteristik yaitu masyarakat sebagai konsumen yang telah mengetahui kualitas produk sepeda motor Suzuki jenis satria FU. Dalam penelitian ini populasinya adalah masyarakat sebagai konsumen sepeda motor Suzuki jenis satria FU150 di kota Bandar Lampung.

\section{Metode Analisis Data}

Sugiyono (2006) menyatakan bahwa: Metode analisis data adalah proses pengelompokan data berdasarkan variable dan respon, mentabulasi data berdasarkan variable dan seluruh responden, menyajikan data tiap variabel yang diteliti, melakukan perhitungan untuk menguji hipotesis yang telah diajukan.

Menurut sugiyono (2006) analisis regresi linier sederhana adalah hubungan secara linear antara satu variabel independen (X) dengan variabel dependen (Y). Analisis ini untuk mengetahui arah hubungan antara variabel independen dengan variabel dependen apakah positif atau negatif dan untuk memprediksi nilai dari variabel dependen apabila nilai variabel independen mengalami kenaikan atau penurunan.

Rumus Persamaan Regresi Linier Sederhana :

$$
Y=a+b X+e
$$

Keterangan:

$$
\begin{aligned}
& \mathrm{Y}=\text { Minat beli } \\
& \mathrm{a}=\text { Konstanta } \\
& \mathrm{b}=\text { Koefisien regresi } \mathrm{X} \\
& \mathrm{X}=\text { Kualitas produk } \\
& \mathrm{e}=\text { Faktor kesalahan }
\end{aligned}
$$


Untuk menguji secara hipotesis secara parsial digunakan Uji t dengan rumus :

$$
t_{\text {hitung }}=\frac{r \sqrt{N-2}}{\sqrt{1-r^{2}}}
$$

Keterangan:

$$
\begin{array}{ll}
\mathrm{t}_{\text {hitung }} & =\text { Nilai } \mathrm{t} \\
\mathrm{r} & =\text { Koefisien Korelasi } \\
\mathrm{N} & =\text { Jumlah responden }
\end{array}
$$

Kriteria untuk Uji $\mathrm{t}$ adalah sebagai berikut :

a) Jika $t_{\text {hitung }}>t_{\text {tabel }}$ maka Ha diterima dan Ho ditolak.

b) Jika $t_{\text {hitung }} \leq \mathrm{t}_{\text {tabel }}$ maka Ha ditolak dan Ho diterima.

\section{HASIL DAN PEMBAHASAN}

Hasil jawaban tentang variabel Kualitas Produk dan Minat Beli Konsumen yang disebarkan kepada 100 responden

\begin{tabular}{|c|c|c|c|c|c|c|c|c|c|c|c|}
\hline \multirow{3}{*}{ (X) } & \multirow{3}{*}{ Peruyatasu } & \multicolumn{10}{|c|}{ Jamaban } \\
\hline & & \multicolumn{2}{|c|}{ SS(5) } & \multicolumn{2}{|c|}{$S(4)$} & \multicolumn{2}{|c|}{$\mathrm{RR}(3)$} & \multicolumn{2}{|c|}{ TS(2) } & \multicolumn{2}{|c|}{ STS(1) } \\
\hline & & $F$ & $\%$ & $F$ & $\%$ & $F$ & $\%$ & $F$ & $\%$ & $\mathrm{~F}$ & $\%$ \\
\hline \multirow[b]{2}{*}{ Kinerja } & 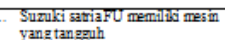 & 22 & 22 & 40 & 40 & 33 & 33 & 5 & 5 & 0 & 0 \\
\hline & 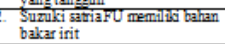 & 20 & 20 & 43 & 43 & 21 & 21 & 6 & 6 & 0 & 0 \\
\hline \multirow{3}{*}{ Fitur } & $\begin{array}{l}\text { Surukk sarriaru menilis body } \\
\text { motor bebolk vang ramping }\end{array}$ & 20 & 20 & 41 & 41 & 32 & 32 & 7 & 7 & 0 & 0 \\
\hline & 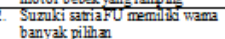 & 18 & 18 & 44 & 44 & 35 & 35 & 3 & 3 & 0 & 0 \\
\hline & 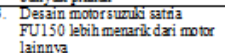 & 18 & 18 & 43 & 43 & 36 & 36 & 3 & 3 & 0 & 0 \\
\hline \multirow{3}{*}{$\begin{array}{c}\text { Resesuaian } \\
\text { dengan } \\
\text { spesifikasi }\end{array}$} & 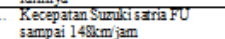 & 13 & 13 & 37 & 37 & 40 & 40 & 10 & 10 & 0 & 0 \\
\hline & $\begin{array}{l}\text { Bentuk body surulid samia Fu } \\
\text { sesuai dengan kem ginan }\end{array}$ & 19 & 19 & 42 & 42 & 32 & 32 & 7 & 7 & 0 & 0 \\
\hline & 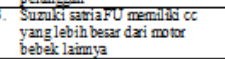 & 18 & 18 & 37 & 37 & 34 & 34 & 11 & 11 & 0 & 0 \\
\hline \multirow{3}{*}{ Daya Tahan } & $\begin{array}{l}\text { Daya tahan man in surubs saria } \\
\text { Fu meniliki garansi msin } 3 \\
\text { tahun }\end{array}$ & 16 & 16 & 38 & 38 & 38 & 38 & 8 & 8 & 0 & 0 \\
\hline & $\begin{array}{l}\text { Daya tahn lampu bisa mencapai } \\
3 \text { bulan }\end{array}$ & 18 & 18 & 38 & 38 & 36 & 36 & 8 & 8 & 0 & 0 \\
\hline & $\begin{array}{l}\text { Suzukik sariaru memilis body } \\
\text { yangkokoh }\end{array}$ & 19 & 19 & 43 & 43 & 33 & 33 & 5 & 5 & 0 & 0 \\
\hline \multirow{3}{*}{ Servicabbility } & $\begin{array}{l}\text { Sparepart Surubs sariaru } \\
\text { mudah didapatlan }\end{array}$ & 22 & 22 & 38 & 38 & 33 & 33 & $?$ & 7 & 0 & 0 \\
\hline & Surukik sarriaru mudah dal am & 15 & 15 & 43 & 43 & 39 & 39 & 3 & 3 & 0 & 0 \\
\hline & $\begin{array}{l}\text { Walktu gervice motor Suruls } \\
\text { satria FU midah dan cepta }\end{array}$ & 23 & 23 & 42 & 42 & 30 & 30 & 5 & 5 & 0 & 0 \\
\hline \multirow{3}{*}{ Estetika } & $\begin{array}{l}\text { Bentuk Surulk sariafu indah } \\
\text { dilihs }\end{array}$ & 16 & 16 & 39 & 39 & 37 & 37 & 8 & 8 & 0 & 0 \\
\hline & 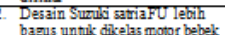 & 17 & 17 & 42 & 42 & 32 & 32 & 9 & 9 & 0 & 0 \\
\hline & $\begin{array}{l}\text { Suzuki sariaru menberilan } \\
\text { wama sestui keinginan } \\
\text { konsumen }\end{array}$ & 20 & 20 & 43 & 43 & 32 & 32 & 5 & 5 & 0 & 0 \\
\hline \multirow{3}{*}{$\begin{array}{l}\text { Persepsi } \\
\text { Kualitas }\end{array}$} & 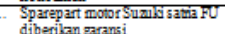 & 15 & 15 & 48 & 48 & 31 & 31 & 6 & 6 & 0 & 0 \\
\hline & 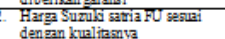 & 16 & 16 & $4 ?$ & $4 ?$ & 33 & 33 & 4 & 4 & 0 & 0 \\
\hline & Suruki sariaru sudah terbenal & 17 & 17 & 40 & 40 & 37 & 37 & 6 & 6 & 10 & 0 \\
\hline
\end{tabular}
ditunjukkan pada Tabel 1 dan Tabel 2.

Tabel 1. Hasil Jawaban Responden variabel Kualitas Produk (X)
Tabel 1. menunjukkan pernyataan variabel Kualitas produk yang direspon

\begin{tabular}{|c|c|c|c|c|c|c|c|c|c|c|c|}
\hline \multirow{3}{*}{ (Y) } & \multirow{3}{*}{ Peruyataan } & \multicolumn{10}{|c|}{ Jamaban } \\
\hline & & \multicolumn{2}{|c|}{ SS(5) } & \multicolumn{2}{|c|}{$S(4)$} & \multicolumn{2}{|c|}{ RR (3) } & \multicolumn{2}{|c|}{$\operatorname{TS}(2)$} & \multicolumn{2}{|c|}{ STS(1) } \\
\hline & & $F$ & $\%$ & $F$ & $\%$ & $F$ & $4 \%$ & F & $\%$ & $F$ & $\%$ \\
\hline \multirow[t]{3}{*}{$\begin{array}{c}\text { NGinat } \\
\text { Transalsional }\end{array}$} & $\begin{array}{l}\text { 1. Sebelum menggunalan Suruls } \\
\text { satria Fu anda telah } \\
\text { mengyunatan menk motor }\end{array}$ & 18 & 18 & 45 & 45 & 33 & 33 & 4 & 4 & 0 & 0 \\
\hline & $\begin{array}{l}\text { 2. Anda selan berkenginan } \\
\text { untuk membeli motor Suruki } \\
\text { satria FU }\end{array}$ & 21 & 21 & 35 & 35 & 37 & 37 & ? & $?$ & 0 & fo \\
\hline & $\begin{array}{l}\text { 3. Dari banyalkj anis motor anda } \\
\text { memilih motor Suruiki satria } \\
\text { FU }\end{array}$ & 20 & 20 & 43 & 43 & 34 & 34 & 3 & 3 & 0 & 0 \\
\hline \multirow{3}{*}{$\begin{array}{l}\text { Minat } \\
\text { Refrensi }\end{array}$} & 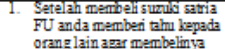 & 20 & 20 & 42 & 42 & 32 & 32 & 6 & 6 & 0 & 0 \\
\hline & 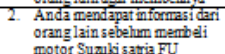 & 22 & 22 & 36 & 36 & 31 & 31 & 1 & 1 & 0 & 0 \\
\hline & 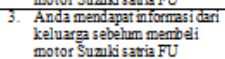 & 19 & 19 & 36 & 36 & 35 & 35 & 10 & 10 & 0 & fo \\
\hline \multirow[t]{3}{*}{$\begin{array}{c}\text { MGinat } \\
\text { Prefensial }\end{array}$} & 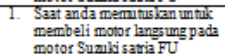 & 18 & 18 & $3 ?$ & 37 & 37 & 37 & 8 & 8 & 0 & 0 \\
\hline & 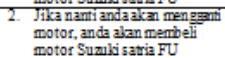 & 20 & 20 & 41 & 41 & 32 & 32 & ? & $?$ & 0 & o \\
\hline & 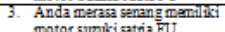 & 22 & 22 & 38 & 38 & 33 & 33 & 7 & $?$ & 0 & 0 \\
\hline \multirow{3}{*}{$\begin{array}{c}\text { Ninat } \\
\text { Eksploratif }\end{array}$} & 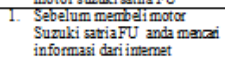 & 15 & 15 & 43 & 43 & 39 & 39 & 3 & 3 & 0 & 0 \\
\hline & 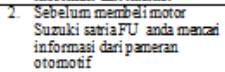 & 23 & 23 & 44 & 44 & 28 & 28 & 5 & 5 & 0 & 0 \\
\hline & 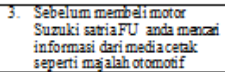 & 19 & 19 & 36 & 36 & 35 & 35 & 10 & 10 & 0 & 0 \\
\hline
\end{tabular}
oleh sampel konsumen.

Tabel 2. Hasil Jawaban Responden Variabel Minat Beli Konsumen (Y)

Dari hasil perhitungan konstanta $\mathrm{a}=$ 13,672 dan $b=0,418$ sehingga persamaan regresinya menjadi $\mathrm{Y}=13,672+0,418 \mathrm{X}$. Persamaan tersebut menunjukan bahwa $\mathrm{a}=$ 13,672 merupakan konstanta yang menunjukan bahwa Minat Beli Konsumen akan tetap memilki nilai terbesar 13,672 tanpa pengaruh Kualitas Produk. $\mathrm{b}=$ Nilai Koefisien Regresi sebesar 0,418 menunjukan bahwa Kualitas Produk akan meningkat sebesar 0,418 apabila ditingkatkan sebesar satu satuan. Dilihat dari nilai beta sebesar 0,576 pada kualitas produk maka dapat mempengaruhi minat beli konsumen.

Nilai koefisien korelasi (R) yang menunjukan tingkat hubungan antar variabel $(0,576)$. Koefisien determinasi $\mathrm{R}^{2}$ (R Square) sebesar 0,331 x $100=33,1$. Menunjukan bahwa minat beli konsumen (Y) dipengaruhi oleh kualitas produk sebesar 33,1\% sedangkan sisanya sebesar $66,9 \%$ dipengaruhi oleh faktor atau variabel lain. 
Hasil analisis regresi linier sederhana diperoleh bahwa nilai thitung 6,968 sedangkan $t_{\text {tabel }} \alpha=0,05$ dan $(\mathrm{df}=\mathrm{n}-2),(100-$ $2=98)$ 1,660 (tabel t). Oleh karena itu thitung $>$ nilai $t_{\text {tabel }}(6,968>1,660)$, maka Ho yang diajukan ditolak dan $\mathrm{Ha}$ diterima artinya Kualitas Produk berpengaruh terhadap minat beli konsumen pada sepeda motor suzuki jenis satria FU di Bandar Lampung.

Dilihat dari keterkaitan antara hasil yang diperoleh kualitas produk yang mempengaruhi minat beli konsumen kondisi ini merupakan perbedaan mutu dan fisik yang menentukan sejauh mana dapat memenuhi persyaratan kebutuhan konsumen yang menentukan nilai mutu dan fisik sampai seberapa jauh nilai tersebut berhubungan dengan produk, jasa, manusia, proses dan lingkungan yang memenuhi atau melebihi kebutuhan mereka.

Sehingga sesuai dengan teori yang diciptakan oleh Fandy Tjiptono (2012). Dan minat beli konsumen adalah aktifitas psikis yang timbul karena adanya perasaan dan pikiran seseorang yang mempunyai keinginan untuk mendapatkan suatu barang atau jasa yang diharapkan atau diinginkan. Teori ini diciptakan oleh (suntana 2005).

\section{KESIMPULAN DAN SARAN}

\section{Kesimpulan}

Berdasarkan hasil perhitungan uji hipotesis dan pembahasan dapat disimpulkan bahwa kualitas produk (X) mempunyai pengaruh terhadap minat beli konsumen (Y), Hal ini dibuktikan dengan hasil analisis regresi linier sederhana diperoleh bahwa nilai thitung adalah 6.968 sedangkan table dengan $\alpha=0,05$ dan df:n-2 $(100-2=98)$ adalah 1,660 (tabel t). Oleh karena nilai $t_{\text {hitung }}>$ nilai $t_{\text {tabel }}(6,968>$ 1,660), maka Ho yang diajukan ditolak dan Ha diterima artinya kualitas Produk berpengaruh terhadap minat beli konsumen pada sepeda motor suzuki jenis satria FU dibandar lampung.

\section{Saran}

Berdasarkan hasil penelitian dan pembahasan, maka penulis dapat sampaikan beberapa saran bagi :

1. Bagi Perusahaan :

Disarankan PT.Suzuki harus memperhatikan kualitas Produk motor Suzuki satria FU seperti kecepatan suzuki satria FU yaitu $150 \mathrm{cc}$ sehingga bisa mencapai tujuan dengan cepat. Dan PT.Suzuki juga harus memperhatikan keluhan dari konsumen seperti Sparepart motor suzuki satria FU diberikan garansi. Supaya konsumen bisa merasa lebih puas dengan produk Suzuki satria FU, sehingga banyak menimbulkan keinginan konsumen untuk menggunakan motor Suzuki satria FU.

2. Bagi Peneliti Selanjutnya

a. Disarankan buat peneliti selanjutnya para peneliti bisa menggunakan teori kotler dan amstrong tentang kualitas produk yang mencerminkan kemampuan produk untuk menjalankan tugasnya yang mencakup daya tahan, kehandalan, atau kemajuan, kekuatan, kemudahan dalam kemasan dan reparasi produk beserta ciri-ciri lainnya.

b. Disarankan untuk peneliti lainnya bisa menggunakan teori menurut engel atau faktor-faktor ini perilaku konsumen dalam melakukan pembelian yaitu faktor lingkungan, perbedaan, individual, dan faktor psikologis.

\section{DAFTAR PUSTAKA}

Daryanto. 2011. Sari Kuliah Manajemen Pemasaran. Bandung: Satu Nusa. 
Hasan, Ali. 2009. Marketing. Yogyakarta: Andi.

Kotler, Philip. 2005. Manajamen Pemasaran, Jilid 1 dan 2. Jakarta: PT. Indeks, Kelompok Gramedia.

Kotler, Philip dan Amstrong Gary. 2007. Manajemen Pemasaran. Edisi Kedua belas jilid 1. Jakarta: Index.

Kotler, Philip dan Lane Keller, Kevin. 2007. Manajemen Pemasaran. Edisi dua belas jilid 1. Jakarta: PT. Index.

2007. Manajemen Pemasaran. Edisi Kedua belas jilid 1. Jakarta: Index.

Sekaran, Uma. 2006. Research Metodhs For Business. Edisi Empat. Jakarta: Salemba Empat.

Sugiyono. 2006. Metodologi Penelitian Bisnis. Bandung: Alfabeta.

Sunyoto, Danang. 2012. Dasar-dasar Manajeman Pemasaran "konsep, strategi dan kasus". Yogyakarta: CAPS Seturan Utama Seleman.

Tjiptono, Fandy. 2012. Service Management. Yogyakarta: Andi. 